Article

\title{
Sa12b Peptide from Solitary Wasp Inhibits ASIC Currents in Rat Dorsal Root Ganglion Neurons
}

\author{
Carmen Hernández ${ }^{1}$, Katsuhiro Konno ${ }^{2}$ (1) , Emilio Salceda ${ }^{1}$, Rosario Vega ${ }^{1}$, \\ André Junqueira Zaharenko ${ }^{3} \mathbb{D}$ and Enrique Soto ${ }^{1, * \mathbb{D}}$ \\ 1 Instituto de Fisiología, Benemérita Universidad Autónoma de Puebla, Puebla 72570, Mexico; \\ mary_car123@hotmail.com (C.H.); emilio.salceda@gmail.com (E.S.); axolotl_56@yahoo.com.mx (R.V.) \\ 2 Institute of Natural Medicine, University of Toyama, Toyama 930-0194, Japan; kkgon@inm.u-toyama.ac.jp \\ 3 Laboratório de Genética, Instituto Butantan, São Paulo 05503-900, Brazil; a.j.zaharenko@gmail.com \\ * Correspondence: enrique.soto@correo.buap.mx or esoto24@gmail.com
}

Received: 30 July 2019; Accepted: 4 October 2019; Published: 10 October 2019

\begin{abstract}
In this work, we evaluate the effect of two peptides Sa12b (EDVDHVFLRF) and Sh5b (DVDHVFLRF-NH ${ }_{2}$ ) on Acid-Sensing Ion Channels (ASIC). These peptides were purified from the venom of solitary wasps Sphex argentatus argentatus and Isodontia harmandi, respectively. Voltage clamp recordings of ASIC currents were performed in whole cell configuration in primary culture of dorsal root ganglion (DRG) neurons from (P7-P10) CII Long-Evans rats. The peptides were applied by preincubation for $25 \mathrm{~s}$ (20 s in $\mathrm{pH} 7.4$ solution and $5 \mathrm{~s}$ in pH 6.1 solution) or by co-application ( $5 \mathrm{~s}$ in $\mathrm{pH} 6.1$ solution). Sa12b inhibits ASIC current with an $\mathrm{IC}_{50}$ of $81 \mathrm{nM}$, in a concentration-dependent manner when preincubation application was used. While Sh5b did not show consistent results having both excitatory and inhibitory effects on the maximum ASIC currents, its complex effect suggests that it presents a selective action on some ASIC subunits. Despite the similarity in their sequences, the action of these peptides differs significantly. Sa12b is the first discovered wasp peptide with a significant ASIC inhibitory effect.
\end{abstract}

Keywords: venom peptides; FMRF-amide; insect neurotoxin; protons; $\mathrm{pH}$ regulation; acid-sensing ion channels; acid-gated currents

Key Contribution: Sa12b, a FMRF-amide like peptide obtained from solitary wasp venom potently inhibits acid-sensing ion channel currents in rat neurons with an $\mathrm{IC}_{50}$ of $81 \mathrm{nM}$.

\section{Introduction}

Acid-sensing ion channels (ASICs) are proton-gated $\mathrm{Na}^{+}$channels of the $\mathrm{ENaC} /$ Degenerin channel family characterized by their sodium permeability, sensitivity to amiloride, and voltage insensitivity [1-4]. ASICs are widely distributed in the central and peripheral nervous systems, as well as in sensory and non-neuronal tissue [5]. Most functions of these channels have been described using inhibitors of ASIC channels combined with the use of knockout or knockdown animals [6]. The most potent and selective modulators of ASICs described to date are animal venoms obtained from spiders, snakes, and sea anemones [7-9].

FMRFa (Phe-Met-Arg-Phe amide) is an abundant tetrapeptide in invertebrate nervous systems, where it acts as a neurotransmitter and neuromodulator. RFa-related peptides share with FMRFa the characteristic C-terminus motive Arg-Phe- $\mathrm{NH}_{2}$ [10]. These neuropeptides are direct activators of two ion channels of the ENaC/Deg superfamily: the invertebrate FMRFa-gated $\mathrm{Na}^{+}$channel $(\mathrm{FaNaC})$ and the Hydra-RFa-gated $\mathrm{Na}^{+}$channels $(\mathrm{HyNaC})$ [11]. 
While $\mathrm{FaNaC}$ and $\mathrm{HyNaC}$ channels are activated by neuropeptides and modulated by acidic $\mathrm{pH}$, ASICs are activated by $\mathrm{pH}$ and modulated by neuropeptides [12]. Several studies show that RFa-related peptides reduce desensitization and increase the sustained current and peak amplitude of ASIC currents [13-18]. These effects are $\mathrm{pH}$-dependent, require the presence of the amide group, and are competitive with $\mathrm{Ca}^{2+}$. Three possible binding sites to ASIC have been proposed: the acidic pocket, the bottom of the thumb domain, and the central vestibule [19-23].

In this work, we studied the effects of two FMRFa related peptides (Sa12b and Sh5b [24,25] extracted from the venom of solitary wasps Sphex argentatus argentatus and Isodontia harmandi) on ASIC currents of rat dorsal root ganglion (DRG) neurons using the voltage clamp technique. We found that Sa12b exerts a potent inhibitory action on ASIC currents in DRG neurons.

\section{Results}

Stable proton-gated currents were recorded from 123 DRG neurons obtained from 32 rats (about $30 \%$ of the cells registered expressed a stable proton-gated current). These neurons had a membrane capacitance $\left(C_{m}\right)$ of $46.8 \pm 1.45 \mathrm{pF}$ (Gaussian fit shows a normal distribution of $C_{m} r^{2}>0.95$ ), a resting membrane potential $\left(\mathrm{V}_{\mathrm{m}}\right)$ of $-55.3 \pm 1.4 \mathrm{mV}$, a membrane resistance $\left(\mathrm{R}_{\mathrm{m}}\right)$ of $137.5 \pm 13.6 \mathrm{M} \Omega$, an access resistance $\left(R_{a}\right)$ of $4 \pm 0.3 \mathrm{M} \Omega$ and a membrane time constant $(\tau)$ of $131 \pm 6.7 \mathrm{~ms}$. Cell average diameter was $38.6 \pm 6.8 \mu \mathrm{m}$, estimated from $\mathrm{C}_{\mathrm{m}}$, which corresponds to medium-size DRG neurons according to Petruska's classification [26].

\subsection{ASIC Current in DRG Neurons}

ASIC currents from isolated DRG neurons showed diverse characteristics, which result from the expression of ASIC heteromers and homomers of ASIC1-4 subunits in these neurons. The currents range from transient and rapid currents with partial or complete desensitization to currents with slow desensitization with a large sustained component (Figure 1). No clear groups could be formed to categorize the currents considering all the parameters analyzed, although according to their desensitization time constant $\left(\mathrm{T}_{\text {des }}\right.$ ), we found that $61 \%$ of the registered currents showed $\mathrm{T}_{\text {des }}<300 \mathrm{~ms}$, $29.5 \% \mathrm{~T}_{\text {des }}>300$ and $<600 \mathrm{~ms}$, while only the remaining $9.5 \%$ had slow kinetics with $\mathrm{T}_{\text {des }}>600 \mathrm{~ms}$.

Under control conditions, the $\mathrm{pH}$ gated currents activated at $\mathrm{pH} 6.1$ showed a maximal inward peak current ( $\mathrm{I}_{\text {peak }}$ ) of $4.5 \pm 0.5 \mathrm{nA}$, a sustained component ( $\left.\mathrm{I}_{\mathrm{SS}}\right)$ of $0.09 \pm 0.01 \mathrm{nA}$, a $\mathrm{T}_{\text {des }}$ of $348 \pm 22 \mathrm{~ms}$, and an integral of the current $\left(\mathrm{I}_{\mathrm{int}}\right)$ of $2.03 \pm 0.171 \mathrm{nC}$. Current density had an average magnitude of $0.097 \pm 0.009 \mathrm{nA} / \mathrm{pF}$ and a desensitization coefficient ( $\mathrm{I}_{\mathrm{SS}} / \mathrm{I}_{\text {peak }}$ ) of $0.04 \pm 0.01$ (mean $\pm \mathrm{ES}, n=95$ ). None of the parameters obtained from the records show any correlation with the $C_{m}$, which is an indicator of cell size. 

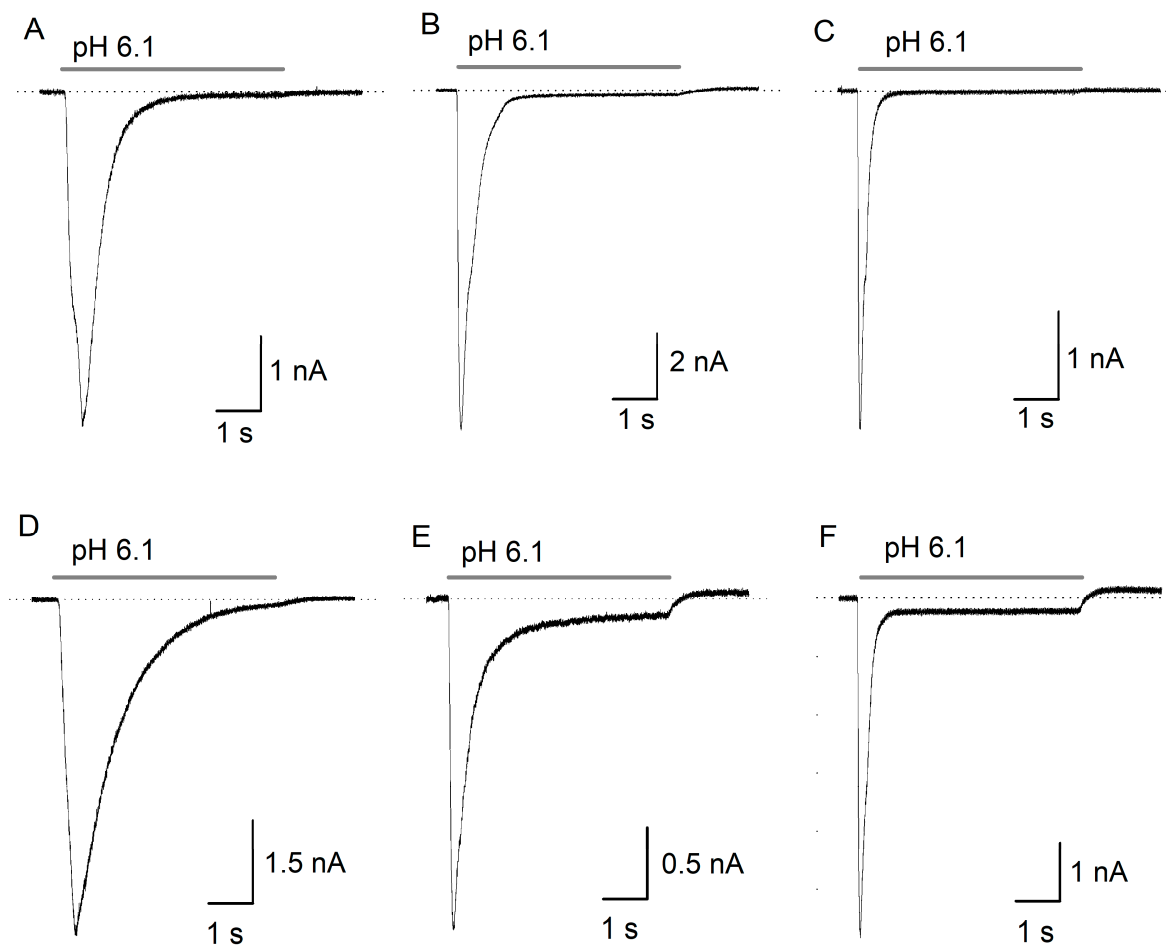

Figure 1. Diversity of acid-gated currents in dorsal root ganglion (DRG) neurons. The currents were elicited by a $5 \mathrm{~s}$ perfusion with a $\mathrm{pH} 6.1$ solution. (A,D) depict currents with slow activation and slow desensitization $(n=9)$. $(\mathbf{B}, \mathbf{E})$, currents with rapid activation and intermediate desensitization $(n=28$. $\mathrm{C}$ and $\mathrm{F}$, currents with rapid activation and rapid desensitization $(n=58)$. $(A-C)$ lack a sustained component (ISS), whereas (D-F) present it.

\subsection{Sa12b Action on ASIC Currents}

The peptide was initially tested at $10 \mu \mathrm{M}$, this concentration was used because it is close to the $\mathrm{EC}_{50}$ of FMRFa. With application of $10 \mu \mathrm{M} \mathrm{Sa} 12 \mathrm{~b}$ in preincubation form $(20 \mathrm{~s}$ before and $5 \mathrm{~s}$ during acid pulse), Sa12b inhibited ASIC currents $92.7 \pm 7.3 \%(p<0.05$ paired Student's $t$-test, $n=5)$ (Figure 2A). In contrast, during co-application (toxin applied only during the $5 \mathrm{~s}$ of acid pulse) Sa12b produced a non-significant inhibition of ASIC currents of $12.9 \pm 4.9 \%(n=4)$ (Figure 2B).

The inhibitory action of Sa12b in $\mathrm{I}_{\text {peak }}$ was dose-dependent with preincubation application (Figures 2A-C and 3), it was adjusted with a dose-response function with an $\mathrm{IC}_{50}=81 \pm 29.4 \mathrm{nM}$, $\mathrm{H}=1.8$ and $\mathrm{r}^{2}=0.97(n=34)$. All Sa12b effects were fully reversed after $1 \mathrm{~min}$ washout of the peptide. Other parameters of ASIC current were not significantly modified by Sa12b perfusion except for the $\mathrm{T}_{\mathrm{des}}$, which increased $28 \%$ with $300 \mathrm{nM}$ Sa12b (Table 1).

To determine whether or not the effect of Sa12b was selective for some type of ASIC current, a correlation analysis between the current properties $\left(\mathrm{I}_{\text {peak }}, \mathrm{T}_{\text {des }}\right.$, and $\left.\mathrm{I}_{\mathrm{SS}}\right)$ and the effect of Sa12b was performed. It was found that the inhibitory effect of Sa12b on ASIC currents does not depend on the $\mathrm{C}_{\mathrm{m}}$, the $\mathrm{T}_{\mathrm{des}}$, or the $\mathrm{I}_{\mathrm{SS}} / \mathrm{I}_{\text {peak }}$ of the control currents; regardless of the concentration tested either during preincubation or co-application of the peptide. 
A
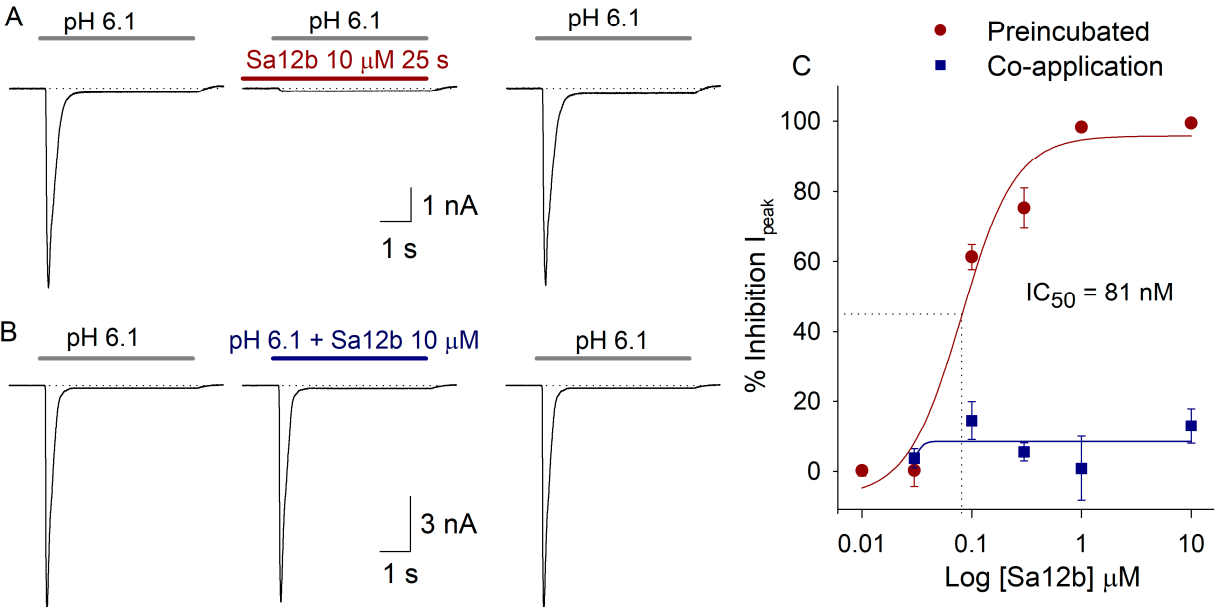

Figure 2. Effect of Sa12b on Acid-Sensing Ion Channels (ASIC) currents. In (A), recordings of ASIC current in dorsal root ganglion (DRG) neurons in control current, after $10 \mu \mathrm{M}$ Sa12b preincubation application ( $20 \mathrm{~s}$ before and $5 \mathrm{~s}$ during acid pulse) and after one recovery of $1 \mathrm{~min}$ washout. Sa12b inhibits the $\mathrm{I}_{\text {peak }}(98 \%)$ of ASIC current with 3\% inhibition of $\mathrm{I}_{\mathrm{SS}}$ component. In (B), $10 \mu \mathrm{M}$ Sa12b co-application (peptide applied during $5 \mathrm{~s}$ along with acid pulse) inhibits $\mathrm{I}_{\text {peak }} 10 \%$ and increases $\mathrm{I}_{\mathrm{SS}}$ by $18 \%$. In (C),

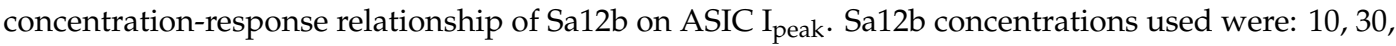
100 , and $300 \mathrm{nM}$ and 1 and $10 \mu \mathrm{M}$. The red circles represent the effect produced by preincubation, and the blue squares represent the effect during co-application of Sa12b $(n=34)$.

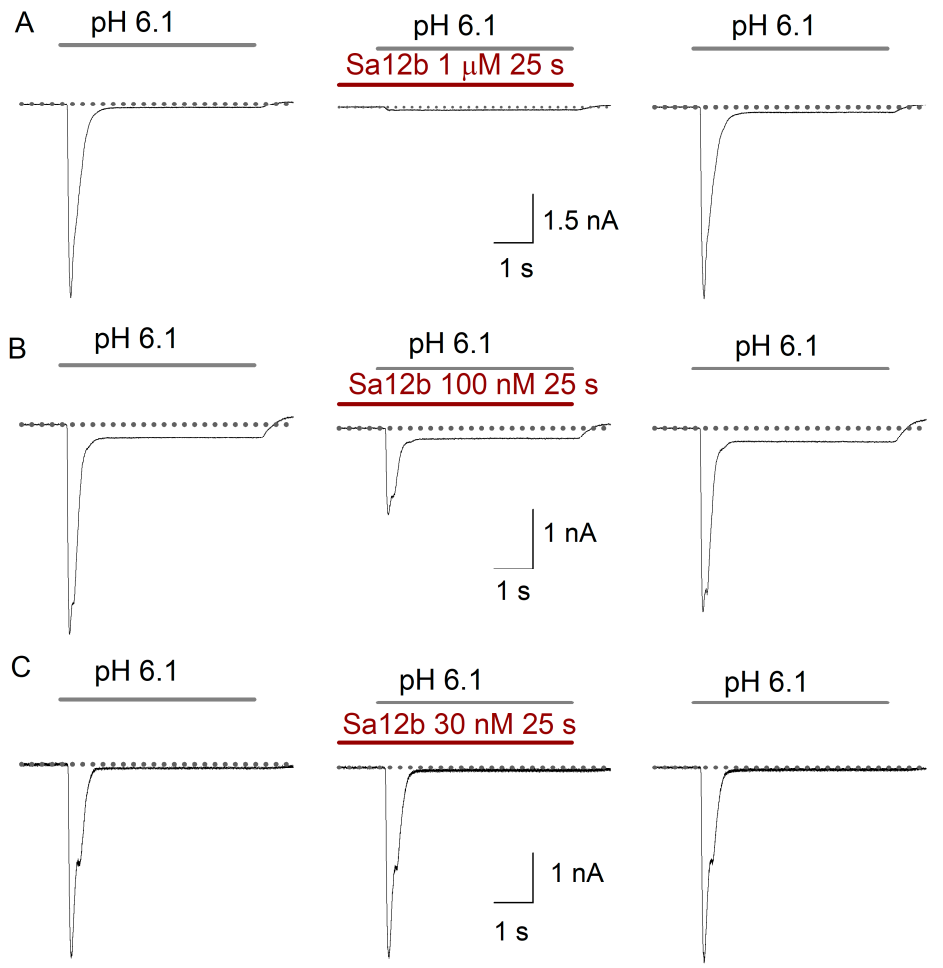

Figure 3. Typical traces of the effect of preincubation perfusion with Sa12b on the ASIC current at the different tested concentrations. In (A), the use of $1 \mu \mathrm{M}$ Sa12b produced a reversible nearly total inhibition of the $\mathrm{I}_{\text {peak }}$ with no effect on the small ISS component. In (B), $100 \mathrm{nM} \mathrm{Sa12b}$ caused an inhibition of $\mathrm{I}_{\text {peak }}$ and $\mathrm{I}_{\mathrm{SS}}$ of $66 \%$ and $7 \%$. In (C), $30 \mathrm{nM} \mathrm{Sa12b}$ produced an inhibition of $\mathrm{I}_{\text {peak }}$ and ISS of $2 \%$ and $10 \%$, respectively. The inhibitory effects of Sa12b were completely reversed after $1 \mathrm{~min}$ washout of the toxin. The dotted lines indicate the zero current, and the horizontal bars show Sa12b preincubation and $\mathrm{pH} 6.1$ perfusion. 
Table 1. Effect of Sa12b on macroscopic Acid-Sensing Ion Channels (ASIC) currents in dorsal root ganglion (DRG) neurons.

\begin{tabular}{|c|c|c|c|c|c|}
\hline & [Sa12b] & $n$ & $\% I_{\text {peak }}$ & $\% I_{S S}$ & $\% \mathrm{~T}_{\text {des }}$ \\
\hline \multirow{5}{*}{ Co-application } & $30 \mathrm{nM}$ & 5 & $\uparrow 4 \pm 3$ & $\begin{array}{l}\uparrow 39 \pm 24 \\
(p=0.02)\end{array}$ & $\downarrow 4 \pm 3$ \\
\hline & $100 \mathrm{nM}$ & 4 & $\downarrow 14 \pm 5$ & $\downarrow 21 \pm 16$ & $\uparrow 5 \pm 1$ \\
\hline & $300 \mathrm{nM}$ & 6 & $\downarrow 5 \pm 3$ & $\downarrow 30 \pm 14$ & $\uparrow 3 \pm 5$ \\
\hline & $1 \mu \mathrm{M}$ & 5 & $\uparrow 1 \pm 9$ & $\uparrow 15 \pm 14$ & $\uparrow 4 \pm 4$ \\
\hline & $10 \mu \mathrm{M}$ & 4 & $\downarrow 13 \pm 5$ & $\downarrow 29 \pm 19$ & $\downarrow 2 \pm 5$ \\
\hline \multirow{5}{*}{$\begin{array}{l}\text { Preincubation } \\
\text { Application }\end{array}$} & $30 \mathrm{nM}$ & 6 & $\downarrow 0.2 \pm 4$ & $\uparrow 19 \pm 22$ & $\uparrow 0.03 \pm 4$ \\
\hline & $100 \mathrm{nM}$ & 5 & $\begin{array}{l}\downarrow 63 \pm 4 \\
(p=0.003)\end{array}$ & $\uparrow 4 \pm 21$ & $\uparrow 17 \pm 18$ \\
\hline & $300 \mathrm{nM}$ & 9 & $\begin{array}{l}\downarrow 76 \pm 5 \\
(p=0.0002)\end{array}$ & $\uparrow 81 \pm 51$ & $\begin{array}{l}\uparrow \mathbf{2 8} \pm \mathbf{1 2} \\
(p=0.048)\end{array}$ \\
\hline & $1 \mu \mathrm{M}$ & 5 & $\begin{array}{l}\downarrow \mathbf{9 8} \pm \mathbf{1} \\
(p=0.03)\end{array}$ & $\downarrow 13 \pm 27$ & \\
\hline & $10 \mu \mathrm{M}$ & 5 & $\begin{array}{l}\downarrow 92 \pm 7 \\
(p=0.04)\end{array}$ & $\downarrow 31 \pm 20$ & \\
\hline
\end{tabular}

The effects that presented a significant difference are shown in red. The upward arrows indicate an increase and the downward arrows indicate a decrease. Student's $t$-test.

\section{3. pH Activation Versus Sa12b Effect}

To determine whether or not Sa12b action is $\mathrm{pH}$-dependent, the effect of Sa12b $100 \mathrm{nM}$ (concentration close to $\mathrm{IC}_{50}$ ) was analyzed as a function of $\mathrm{pH}$ used to activate the current ( $\mathrm{pH}$ from 4.0 to 6.5). As previously described, the current amplitude increased as a function of proton concentration (Figure $4 \mathrm{~A}, \mathrm{~B})$. The $\mathrm{pH}$ which activated $50 \%$ of the ASIC current $\left(\mathrm{pH}_{50}\right)$ was about 6.1 as previously described for ASIC currents in DRG neurons [27]. The relationship between $\mathrm{pH}$ and proton-gated current amplitude in the presence of $100 \mathrm{nM}$ Sa12b showed no significant difference with that found in control condition (Figure 4B). Analysis of percent inhibitory effect of $100 \mathrm{nM} \mathrm{Sa12b}$ as a function of $\mathrm{pH}$ showed that $\mathrm{pH}$ gating of the current did not significantly modify the inhibitory action of $\mathrm{Sa} 12 \mathrm{~b}$ (Figure $4 \mathrm{C}$ ). These data indicate that Sa12b does not interact with the proton-gating mechanism of ASICs. 

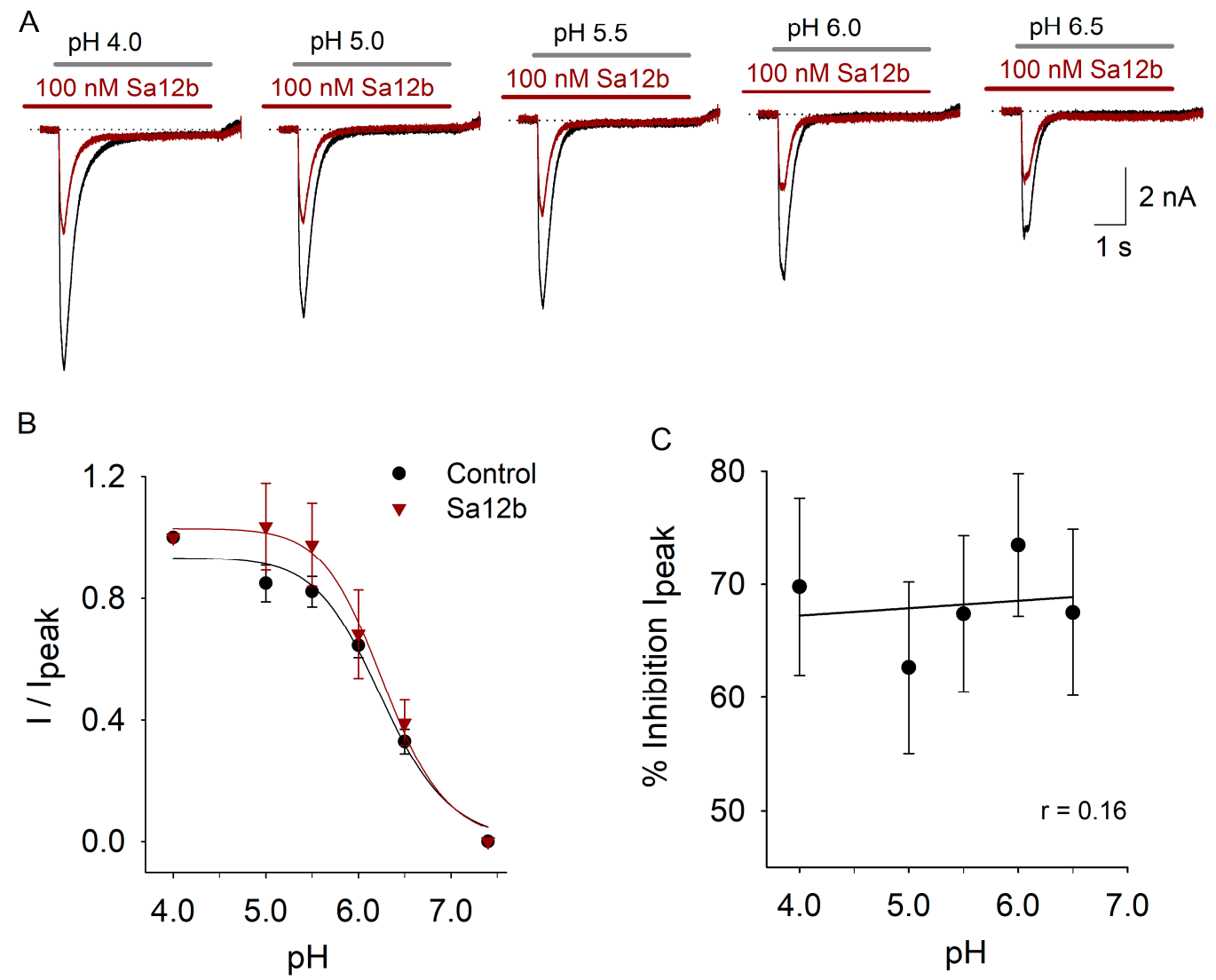

Figure 4. Effect of pH-gating the ASIC current on Sa12b action. In (A), recordings of ASIC current at different gating $\mathrm{pHs}$ in control (black traces) and after preincubation with $100 \mathrm{nM} \mathrm{Sa12b}$ (red traces). The inhibitory effect of $\mathrm{Sa} 12 \mathrm{~b}$ is similar regardless of the $\mathrm{pH}$ used to activate the current. All recordings are from the same cell, which desensitize nearly completely and shows small ISs component. In (B), relation between the $\mathrm{pH}$ used to activate the current and the normalized $\mathrm{I}_{\text {peak }}$ in control (black) and after $100 \mathrm{nM}$ Sa12b. Data were adjusted with a sigmoidal function, no significant difference between

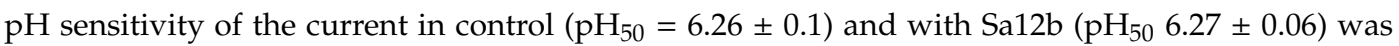

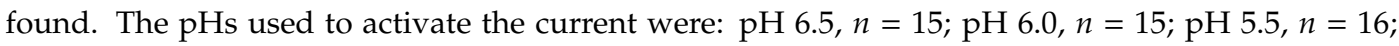
$\mathrm{pH} 5.0, n=17 ; \mathrm{pH} 4.0, n=14$. In (C), plot of the percent $\mathrm{I}_{\text {peak }}$ inhibition produced by $100 \mathrm{nM} \mathrm{Sa12b}$ against $\mathrm{pH}$. The data were adjusted with a linear function showing that inhibition produced by Sa12b is independent of the $\mathrm{pH}$ used to activate the ASIC current.

\subsection{Effect of Sh5b}

As with Sa12b peptide, the application of Sh5b peptide was carried out under co-application and preincubation. The concentrations at which the peptide was tested were: for co-application $100 \mathrm{nM}$, $3 \mu \mathrm{M}, 10 \mu \mathrm{M}$, and $30 \mu \mathrm{M}$; for preincubation application, the concentrations were $100 \mathrm{nM}, 1$ and $10 \mu \mathrm{M}$.

In the co-application protocol, $100 \mathrm{nM} \mathrm{Sh} 5 \mathrm{~b}(n=5)$ showed no consistent concentration-dependent effects on the analyzed parameters. At $3 \mu \mathrm{M} \operatorname{Sh} 5 \mathrm{~b}(n=12)$ decreased the $\mathrm{T}_{\text {des }}$ by $7 \%(p=0.046)$ with highly variable non-significant increase of the $\mathrm{I}_{\mathrm{SS}}$. Increasing Sh5b concentration to $10 \mu \mathrm{M}$ produced an increase of the $\mathrm{I}_{\text {peak }}$ in some cells and a decrease in other group, but overall change was non-significant (Table 2). Other parameter changes were also non-significant. At $30 \mu \mathrm{M}$ Sh5b $(n=6)$ increased the ISS $78 \pm 16 \%$ ( $p=0.004)$ (Figure 5). However, the observed effects on ASIC current when using Sh5b in co-application were not dependent on concentration (Table 2). 
Table 2. Effect of Sh5b on macroscopic ASIC currents in DRG neurons.

\begin{tabular}{cccccc}
\hline & {$[\mathbf{S a 1 2 b}]$} & $\mathbf{n}$ & \% I $_{\text {peak }}$ & \% ISS & \% $_{\text {des }}$ \\
\hline \multirow{3}{*}{ Co-application } & $100 \mathrm{nM}$ & 5 & $\downarrow 2 \pm 4$ & $\uparrow 85 \pm 74$ & $\downarrow 1 \pm 2$ \\
\cline { 2 - 6 } & $3 \mu \mathrm{M}$ & 12 & $\downarrow 6 \pm 3$ & $\uparrow 116 \pm 104$ & $\downarrow 7 \pm 4$ \\
\cline { 2 - 6 } & $10 \mu \mathrm{M}$ & 9 & $\uparrow 17 \pm 15$ & $\uparrow 1 \pm 11$ & $\downarrow 10 \pm 5$ \\
\cline { 2 - 6 } & $30 \mu \mathrm{M}$ & 6 & $\downarrow 1 \pm 6$ & $\uparrow 78 \pm 16$ & $\uparrow 9 \pm 5$ \\
\hline \multirow{2}{*}{$\begin{array}{c}\text { Preincubation } \\
\text { application }\end{array}$} & $100 \mathrm{nM}$ & 9 & $\downarrow 0.5 \pm 6$ & $\uparrow 53 \pm 38$ & $\uparrow 13 \pm 15$ \\
\cline { 2 - 6 } & $1 \mu \mathrm{M}$ & 5 & $\downarrow 9 \pm 5$ & $\uparrow 14 \pm 41$ & $\uparrow 3 \pm 5$ \\
\cline { 2 - 6 } & $10 \mu \mathrm{M}$ & 12 & $\downarrow 11 \pm 4$ & $\downarrow 8 \pm 15$ & $\downarrow 5 \pm 4$ \\
\hline
\end{tabular}

The effects that presented a significant difference are shown in red. The upward arrows indicate an increase and the downward arrows indicate a decrease. Student's $t$-test.

The use of $100 \mathrm{nM} \mathrm{Sh} 5 \mathrm{~b}$ in preincubation $(n=9)$ produced no effect on the analyzed parameters. Perfusion of $1 \mu \mathrm{M}$ Sh $5 \mathrm{~b}(n=5)$ produced a marginal decrease of the $\mathrm{I}_{\text {peak }}(9 \pm 5 \%)$, and an increase of the ISS, both effects were non-significant. $10 \mu \mathrm{M}$ Sh $5 \mathrm{~b}(n=12)$ did not produced significant effects on the studied parameters either (Figure 6, Table 2).

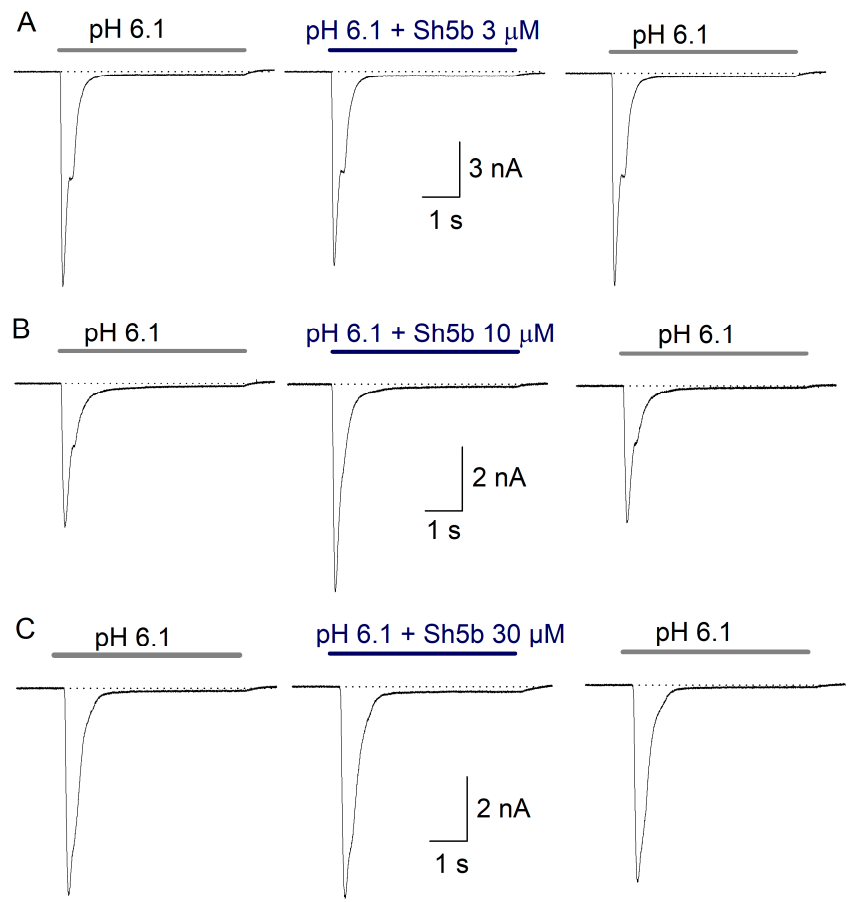

Figure 5. Effect of Sh5b peptide on ASIC currents of DRG neurons. Graphs show ASIC current in control, co-application, and after one minute of peptide washout. In (A), co-application of $3 \mu \mathrm{M}$ Sh5b reduced $\mathrm{I}_{\text {peak }}$ of ASIC currents by $9.6 \%$, while ISS was increased by $30 \%$. In (B), co-application of $10 \mu \mathrm{M}$ Sh $5 \mathrm{~b}$, increased $\mathrm{I}_{\text {peak }}$ by $44.6 \%$ and $\mathrm{I}_{\mathrm{SS}} 14.6 \%$. In (C), the co-application of $30 \mu \mathrm{M}$ Sh $5 \mathrm{~b}$ caused an inhibition of $3.8 \%$ on $\mathrm{I}_{\text {peak }}$ and an increase of $102 \%$ on $\mathrm{I}_{\mathrm{SS}}$ from $79 \mathrm{pA}$ to $159 \mathrm{pA}$. Effects were reversed by 1 min peptide washout. 


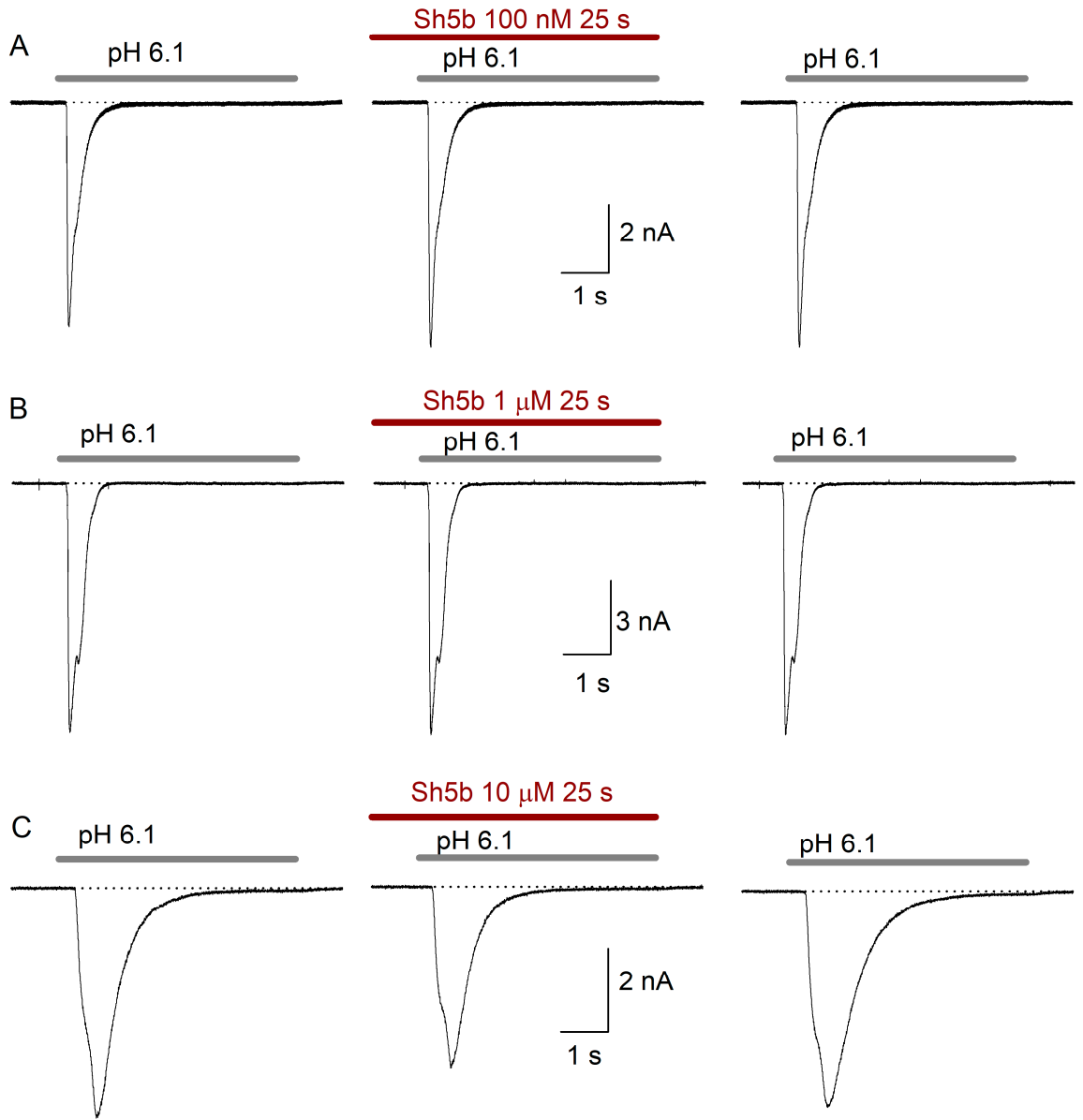

Figure 6. Graphs showing the effect of Sh5b preincubation on ASIC currents. Recordings show ASIC current under control conditions, after preincubation with $\mathrm{Sh} 5 \mathrm{~b}$ and after one-minute peptide washout. In (A), shows the effect of preincubation with $100 \mathrm{nM} \mathrm{Sh} 5 \mathrm{~b}$, which produced a marginal increase of the $\mathrm{I}_{\text {peak }}$ and $\mathrm{I}_{\mathrm{SS}}$ of $1 \%$ and $3 \%$ respectively, with no change in $\mathrm{T}_{\text {des. }}$. In (B), preincubation with $1 \mu \mathrm{M}$ Sh $5 \mathrm{~b}$ inhibits $\mathrm{I}_{\text {peak }}$ and $\mathrm{I}_{\mathrm{SS}}$ by $1 \%$ and $5 \%$ respectivley. In (C), use of $10 \mu \mathrm{M}$ Sh $5 \mathrm{~b}$ inhibits the $\mathrm{I}_{\text {peak }}$ by $18 \%$ and increased the $I_{S S}$ by $26 \%$, with no change in $T_{\text {des. }}$. The effect was reversed by 1 min washout of the peptide.

\section{Discussion}

\section{1. $S a 12 b$}

Sa12b peptide, when applied by preincubation, reversibly inhibits the amplitude of the peak of ASIC currents $\left(\mathrm{IC}_{50} \sim 81 \mathrm{nM}\right)$ in rat DRG neurons in a concentration-dependent manner without consistent action on the time course of desensitization or the sustained component of the current. Currents activated by $\mathrm{H}^{+}$in DRG neurons are heterogeneous due to the combination of two or more ASIC subunits with coexistence of multiple populations of channels in the same cell [28-31]. The inhibitory effect of $\mathrm{Sa} 12 \mathrm{~b}$ was similar in all cells regardless of the kinetics of currents, which indicates that Sa12b action is not specific to any particular ASIC subunit; however, this question requires further exploration on channels expressed in a heterologous system.

We found no effect on the $\mathrm{I}_{\text {peak }}$ during co-application of Sa12b and acidic $\mathrm{pH}$. That the inhibitory effect of Sa12b was observed only after preincubation application suggests that the peptide needs to interact with the channel during its closed state; an alternative explanation would be that this effect is due to a slow interaction of the peptide with ASIC or a slow conformational change of the channel 
induced by Sa12b [21]. RFa-related peptides also seem to produce their modulating effect only when applied before acid gating of the channel [20].

The inhibitory potency of $\mathrm{Sa} 12 \mathrm{~b}\left(\mathrm{IC}_{50}=81 \mathrm{nM}\right)$ on ASIC currents is comparable to the inhibition caused by peptides of vegetable and animal origin, such as chlorogenic acid (CGA, polyphenol) and the gastrodin (phenol) that inhibits ASIC currents in rat DRG neurons $\left(\mathrm{IC}_{50} \sim 230 \mathrm{nM}\right.$ and $\sim 210 \mathrm{nM}$ respectively) [32,33]. APETx2 (from the sea anemone Anthopleura elegantissima) inhibits the homomeric channels of rASIC3 $\left(\mathrm{IC}_{50} 37-63 \mathrm{nM}\right.$ ) and hASIC3 $\left(\mathrm{IC}_{50} \sim 175 \mathrm{nM}\right)$ [34]; mambalgines (from the black mamba and the green mamba) inhibit the homomers of ASIC1a and ASIC1b, and the heteromers containing ASIC1a with an $\mathrm{IC}_{50}$ ranging from 11 to $250 \mathrm{nM}[35,36]$; or PhcrTx1 peptide extracted from Phymanthus crucifer $\left(\mathrm{IC}_{50} \sim 100 \mathrm{nM}\right.$ ) which inhibits ASIC currents $\cong 40 \%$ [37]. The inhibitory effect of Sa12b in ASIC currents is only surpassed in potency by two known ASIC1a inhibitors: PcTx1, from tarantula venom Psalmopoeus cambridgei $\left(\mathrm{IC}_{50}=1 \mathrm{nM}\right)[38]$ and Hi1a, from the venom of the Australian spider Hadronyches infensa $\left(\mathrm{IC}_{50}=0.4-0.5 \mathrm{nM}\right)$, however, PcTx1 behaves as an agonist of ASIC1b $\left(\mathrm{EC}_{50} \sim 100 \mathrm{nM}\right)$, while Hila produces an incomplete current inhibition at saturating concentration $(1 \mu \mathrm{M})$ [9]. It is worth note that Sa12b produces a close to $100 \%$ inhibition of $\mathrm{I}_{\text {peak }}$ at $1 \mu \mathrm{M}$. Which suggests that Sa12b exerts an unspecific action among ASIC subunits, although the lack of inhibition of ISS suggest some kind of selectivity among ASIC subunits. To define this, it will be needed to perform experiments in a heterologous expression system studying the action of Sa12b on specific homomers of ASIC subunits.

It is speculated that modulation of ASIC channels by RFa-related peptides is due to direct interaction between the peptide and the extracellular domain of the channel having the lower region of the palmar domain of the channel as a probable binding site, specifically the region occupied by the central vestibule of the channel; furthermore, it has been suggested that RFa-related peptides bind to the channel in the closed state and dissociate very slowly from the desensitized state [22]. Since Sa12b has a very short amino acid sequence, binding in the central vestibule may plug the channel, decreasing the conductance instead of slowing inactivation and desensitization of ASIC currents, which is what RFa does.

Sa12b sequence (EDVDHVFLRF) suggests the presence of a hydrophobic patch provided by the amino acids: Val3, Val6, Phe7, Leu8, and Phe10; the Phe15 residue in APETx2 is of great importance for this toxin to inhibit the currents of ASIC3 [39]. Similarly, PcTx1 has a hydrophobic patch conferred by Trp7 and Trp24 which interacts with the thumb domain of the ASIC channel, while the basic group of PcTx1 (Arg26, Arg27, and Arg28) enters the acidic pocket to form strong hydrogen bonds [40]. Sa12b also possesses two residues with a positive charge (His5 and Arg9) that could be a binding site with ASIC channels.

\section{2. $\operatorname{Sh} 5 b$}

Sh5b did not produce consistent, reproducible, effects on ASIC currents, it shows various effects on most of the analyzed parameters, including dual effects on the $\mathrm{I}_{\text {peak }}$ and $\mathrm{T}_{\text {des }}$. The complex action of Sh5b suggests that this peptide presents selective action on some subunits of ASICs. As already mentioned, the macroscopic currents activated by $\mathrm{H}^{+}$in the DRG neurons present a morphological heterogeneity resulting from the combination of two or more ASIC subunits, so the inconsistent action of Sh5b could be given by selectivity of the peptide for some ASIC subunits. Future studies using heterologous expression of ASIC subunits could clarify whether Sh5b possesses any selectivity; if so, Sh5b can become a pharmacological tool that allows studying specific ASIC subunits.

Application of Sh5b by preincubation showed a tendency to inhibit the current peak. The ISS component increased slightly after application of $S h 5 b$, and the $I_{S S} / I_{\text {peak }}$ relationship also increased; this last parameter was the one that had statistically significant effects in the greatest number of the tested concentrations, which suggests a modification on the desensitization process of ASICs. However, the $\mathrm{T}_{\text {des }}$ and the integral of the current show no consistent changes, exhibiting dual effects. 
During co-application, the $\mathrm{I}_{\mathrm{SS}} / \mathrm{I}_{\text {peak }}$ relationship showed a tendency towards the increase, but the $\mathrm{T}_{\text {des }}$ did not show noticeable differences.

$\mathrm{RFa}$-related peptides have an $\mathrm{NH}_{2}$ group which is positively charged at $\mathrm{pH} 5$ to 8 [21]. The effects of $S h 5 b$ could be due to the positive charge given by its amine group. Other inhibitors of ASICs, such as the PhcrTx1 peptide, which at $\mathrm{pH} 7.4$ has a net charge of +5.03 , APETx2 (net charge $=+2.00$ ), and PcTx1 $($ net charge $=+3$ ) [37] also have that particularity. Aminoglycosides are also positively-charged ASICs modulators [27].

Analysis of the structure of Sa12b (EDVDHVFLRF) and Sh5b (DVDHVFLRFa) showed that Sa12b has an extra Glu in its N-terminal, while Sh5b has an amide residue in its C-terminal. Sa12b has three negatively charged amino acids (Glu1, Asp2, and Asp4) and two positively charged ones (His5 and Arg9), which gives the peptide a negative net charge, besides it has four polar amino acids (Glu1, Asp2, Asp4, and Arg9) and six apolar ones (Val3, His5, Val6, Phe7, Leu8, Phe10). In contrast, Sh5b presents in its sequence two negatively charged amino acids (Asp1 and Asp3) and two positively charged ones (His4 and Arg8), which makes it a peptide with neutral charge. With respect to solubility, Sh5b consists of three polar amino acids (Asp1, Asp3, and Arg8) and six apolar ones (Val2, His4, Val5, Phe6, Leu7, Phe9). These structural differences, mainly the difference of net charges, could favor differences in the folding of the tertiary structure, which could produce the differences in the interaction of $S a 12 b$ and Sh5b with ASIC.

\section{Conclusions}

The results from this work show that the application of Sa12b exerts an inhibitory effect on ASIC currents from DRG neurons, this effect was concentration-dependent and reversed after washout of the peptide. Since the inhibition was close to $100 \%$ at $1 \mu \mathrm{M}$ and all ASIC subunits are expressed in DRGs, it suggests that Sa12b inhibits different ASIC subunits without an apparent selectivity. Sa12b is the first discovered wasp peptide with a significant ASIC inhibitory action.

\section{Material and Methods}

\subsection{Animals and Cell Culture}

To study the effect of Sa12b and Sh5b on ASIC, DRG neurons were obtained from Long-Evans CII / ZV rats of 7 to 10 days of postnatal age, of either sex. Animals were provided by the laboratory animal facility 'Claude Bernard' of the Autonomous University of Puebla. The study was performed in accordance with the recommendations in the Guiding Principles in the Care and Use of Vertebrate Animals in Research and Training of the American Physiological Society, and with the regulations of the NOM-062-ZOO-1999 of the Mexican Ministry of Agriculture, Stockbreeding, Rural Development, Fishing and Food. The protocol was reviewed and approved by the Institutional Committee for Animal Care and Use (IACUC) of the Autonomous University of Puebla (VIEP-BUAP) on 17 July 2017. The ethical approval code is SOEE-UALVIEP-17-1. All efforts were made to minimize animal suffering and to reduce the number of animals used. DRG neurons were isolated and maintained in primary culture according to the methodology described previously [41]. The dissection and cell culture were performed within a level I biosafety laminar flow hood (Nuaire, Plymouth, MN, USA). Rats were anesthetized with sevoflurane and sacrificed by decapitation. Subsequently, the rat was placed in prone position to make a longitudinal incision through the vertebral bodies removing the spinal cord. Dorsal root ganglia were isolated (approximately 12 to 18 per rat) using conventional dissection under a stereoscopic microscope (American Optical, Southbridge, MA, USA). Once extracted, DRG neurons were placed in a disposable sterile centrifuge tube (Corning, Corning, NY, USA), in which they were incubated for $30 \mathrm{~min}$ at $37^{\circ} \mathrm{C}$ in Leibovitz L15 medium (L15) (Invitrogen, Waltham, MA, USA), added with $1.25 \mathrm{mg} / \mathrm{mL}$ of trypsin and $1.25 \mathrm{mg} / \mathrm{mL}$ of collagenase (both from Sigma-Aldrich, St. Louis, MO, USA) for an enzymatic dissociation. 
After the enzymatic treatment, the ganglia were washed 3 times with 100\% L15 medium; after each wash, the cells were subjected to mechanical dissociation using glass three-gauge Pasteur pipettes; between each wash, a cell pellet was formed using a centrifuge at $5000 \mathrm{rpm}$. After the third wash, once the cell pellet was formed, the supernatant was discarded, and the cell suspension was placed in a $35 \mathrm{~mm}$ culture dish (Corning) on $12 \times 10 \mathrm{~mm}$ glass plates (Corning) previously treated with poly-D-lysine (Sigma-Aldrich, St. Louis, MO, USA).

Dissociated neurons were incubated for a period of time ranging from 2 to $8 \mathrm{~h}$ in a humidified atmosphere $\left(95 \% \mathrm{O}_{2}, 5 \% \mathrm{CO}_{2}\right.$, at $\left.37^{\circ} \mathrm{C}\right)$ using a water-jacketed $\mathrm{CO}_{2}$ incubator (Nuaire, Plymouth, $\mathrm{MN}$, USA) allowing for settlement and adhesion of isolated cells to the glass plates. The cells were cultured in modified L15 medium, supplemented with 10\% fetal bovine serum (Gibco, Waltham, MA, USA), $100 \mathrm{IU}$ penicillin (Lakeside, Hayward, CA USA), fungizone $2.5 \mu \mathrm{L} / \mathrm{mL}$ (Gibco), $\mathrm{NaHCO}_{3} 15.7 \mathrm{mM}$ (J.T. Baker, Radnor DE, USA) and 15.8 mM HEPES (Sigma-Aldrich, St. Louis, MO, USA).

\subsection{Recording of ASIC Currents in DRG Neurons}

After an incubation period of 2 to $8 \mathrm{~h}$, the recording of ASIC currents in DRG neurons was performed. Cells were transferred to a recording chamber mounted in a phase-contrast inverted microscope (TMS, Nikon Co. Tokyo, Japan). Neurons that were not attached to other cells, and that had a round or ovoid shape (without dendritic or axonal extensions) with a delimited refringent membrane were chosen for recording.

The recording chamber was constantly perfused with extracellular solution (Table 3). Recordings were performed in whole-cell voltage-clamp mode using an Axopatch 1D amplifier (Molecular Devices, Union City, CA, USA). Data collection and generation of commands for the perfusion change were carried out by the pClamp 9.2 (Molecular Devices) software in a 16-bit data acquisition system (Digidata 1320, Molecular Devices). Microelectrodes were made from borosilicate glass capillaries (TW120-3; WPI, Sarasota, FL, USA) with a micropipette puller (80-PC; Sutter Instruments Company, San Rafael, CA, USA), which once filled with the intracellular solution (Table 3) had a resistance of 1.4 to $3.1 \mathrm{M} \Omega$. The signals were digitized at $5 \mathrm{kHz}$. The series resistance was electronically compensated at $80 \%$. Throughout the recording, access resistance and seal quality were monitored to ensure stable recording conditions. The records that showed a $>10 \%$ change in access resistance compared to the initial conditions were excluded from data analysis.

Table 3. Solutions used for electrophysiological recording.

\begin{tabular}{cccc}
\hline & Extracellular [mM] & Acid Solution [mM] & Intracellular [mM] \\
\hline $\mathrm{NaCl}$ & 140 & 140 & 10 \\
$\mathrm{KCl}$ & 5.4 & 5.4 & 125 \\
$\mathrm{CaCl}_{2}$ & 1.8 & 1.8 & 0.134 \\
$\mathrm{MgCl}_{2}$ & 1.2 & 1.2 & - \\
$\mathrm{HEPES}$ & 10 & - & 5 \\
$\mathrm{MES}$ & - & 10 & - \\
D-glucose & 10 & - & - \\
EGTA & - & - & 10 \\
ATP- Mg & - & - & 2 \\
GTP-Na & - & adjusted to desired pH & adjusted to pH 7.2 with \\
& adjusted to $\mathrm{pH} 7.4$ with & with NaOH & KOH \\
\hline
\end{tabular}

Proton-gated currents were obtained with a holding potential of $-60 \mathrm{mV}$. Cells were subjected to a test protocol with an acid solution of $\mathrm{pH} 6.1$ for $5 \mathrm{~s}$ (Table 3). In all the experiments at least two control recordings were made before performing some type of experimental manipulation in order to guarantee that the cells expressed a stable proton-gated current; the margin of variation in the amplitude of the current between one control recording and another should be less than $10 \%$. 


\subsection{Wasp Peptides}

The peptides Sa12b (EDVDHVFLRF, molecular weight $=1276.4 \mathrm{~g} / \mathrm{mol}$ ) and Sh5b $($ DVDHVFLRF-NH2, molecular weight $=1146.3 \mathrm{~g} / \mathrm{mol})$ were purified from the venom extracts of solitary wasps Sphex argentatus argentatus and Isodontia harmandi, respectively, and the structure was determined by MALDI-TOF/TOF MS analysis (manuscript in preparation). The synthetic specimens of these peptides were used in this study.

\subsection{Peptide Synthesis}

The peptide was synthesized on an automated PSSM-8 peptide synthesizer (Shimadzu Corp., Kyoto, Japan) by a stepwise solid-phase method using N-9-fluorenylmethoxycarbonyl (Fmoc) chemistry. All the resins and Fmoc-L-amino acids were purchased from HiPep Laboratories (Kyoto, Japan). Cleavage of the peptide from the resin was achieved by treatment with a mixture of TFA/ $\mathrm{H}_{2} \mathrm{O}$ /triisopropylsilane (TIS) (95:2.5:2.5) at room temperature for $2 \mathrm{~h}$. After removal of the resin by filtration and washing twice with trifluoroacetic acid (TFA), the combined filtrate was added dropwise to diethyl ether at $0{ }^{\circ} \mathrm{C}$ and then centrifuged at $3000 \mathrm{rpm}$ for $10 \mathrm{~min}$. Thus, obtained crude synthetic peptide was purified by semipreparative reverse-phase HPLC using CAPCELL PAK $\mathrm{C}_{18}, 10 \times 250 \mathrm{~mm}$ with isocratic elution of $20-25 \% \mathrm{CH}_{3} \mathrm{CN} / \mathrm{H}_{2} \mathrm{O} / 0.1 \%$ TFA at a flow rate of $3 \mathrm{~mL} / \mathrm{min}$. The homogeneity and the sequence were confirmed by MALDI-TOF MS and analytical HPLC.

\subsection{Experimental Design and Data Analysis}

ASIC currents were activated by micro-perfusion of the cell under recording with an acid solution (pH 6.1) through a square tube using a rapid perfusion exchange system (SF-77B, Warner Inst., Hamden, $\mathrm{CT}$, USA). The $\mathrm{pH}$-gated current was activated using a $\mathrm{pH}$ of 6.1 which coincides with the $\mathrm{pH}_{50}$ previously demonstrated for ASIC currents in DRG neurons [41]. Capsazepine $10 \mu \mathrm{M}$ was added to the extracellular solution at $\mathrm{pH} 6.1$ in order to limit the activation of TRPV1 receptors, which are also sensitive to acid and are expressed in DRG neurons [42]. To study the effect of Sa12b and Sh5b peptides on ASIC currents of DRG neurons two application protocols were used [41]. Peptides were applied by sustained application (preincubation) and by co-application. In the preincubation, the toxin was applied through the $\mathrm{pH} 7.4$ extracellular solution for $20 \mathrm{~s}$ before the acid pulse and during the $5 \mathrm{~s}$ that the acid pulse lasted. In co-application, the compound was applied only during the 5-second acid pulse. The effects observed during preincubation result from channel exposure to the peptide during the closed, open, and desensitized states. During co-application the toxins interacts with the channel in the open and desensitized states.

The passive properties of the neurons were recorded in each experiment, including the membrane capacitance $\left(C_{m}\right)$, cell-membrane voltage $\left(V_{m}\right)$, membrane resistance $\left(R_{m}\right)$, and access resistance $\left(R_{a}\right)$. Solutions were prepared at the time of experiment; the peptides were kept frozen at $-20^{\circ} \mathrm{C}$ in aliquots at different concentrations in deionized water added with $1 \mathrm{mg} / \mathrm{mL}$ of albumin (Sigma-Aldrich) to prevent the peptides from adhering to the walls of the perfusion tubes.

The proton-gated currents were processed offline using the software Clampfit 9.2 (Molecular Devices), Microsoft Office Excel 2010 and SigmaPlot 12.0. For each experimental condition two control recordings were obtained, one recording with the application of the peptide, and two washout recordings. The problem currents were normalized with respect to the average of the control currents in order to obtain the percentage of change in the parameters measured in the presence of the toxins.

For the analysis of the toxin actions, the concentration-response curves were adjusted with a Hill equation:

$$
\mathrm{Y}=\mathrm{A}_{2}+\left(\mathrm{A}_{1}-\mathrm{A}_{2}\right) /\left(1+\left(\mathrm{x} / \mathrm{E}_{50}\right) \mathrm{H}\right)
$$

where: $\mathrm{Y}=$ Pharmacological effect, $\mathrm{x}=$ Concentration tested, $\mathrm{A}_{1}$ and $\mathrm{A}_{2}=$ Maximum and minimum effect, $\mathrm{E}_{50}=$ Concentration in which $50 \%$ of the effect is obtained, $\mathrm{H}=$ Hill constant. 
To study the desensitization of the current, a simple exponential function was adjusted, obtaining the decay constant of the current $\left(\mathrm{T}_{\mathrm{des}}\right)$.

To determine the statistical significance of the data, a paired Student's $t$-test was used and $p$ values reported; the experimental data are presented as the mean \pm E.S.

Author Contributions: Conceptualization, K.K., A.J.Z. and E.S. (Enrique Soto); Methodology, K.K., E.S. (Emilio Salceda) and R.V.; Validation, E.S. (Enrique Soto) and R.V.; Investigation, C.H., E.S. (Enrique Soto), E.S. (Emilio Salceda); Writing-Review \& Editing, C.H., E.S. (Enrique Soto), R.V. and K.K.

Funding: This study was supported by grant from Vicerrectoría de Investigación y Estudios de Posgrado (VIEP-BUAP grants to ES) and grant from Consejo Nacional de Ciencia y Tecnología de México (CONACyT), Fronteras de la Ciencia 1544 to E.S. Enrique Soto. CHZ was supported by CONACyT fellowship 669573.

Conflicts of Interest: The authors declare no competing financial interest. The data that support the findings of this study are available from the corresponding author upon reasonable request.

\section{References}

1. Boscardin, E.; Alijevic, O.; Hummler, E.; Frateschi, S.; Kellenberger, S. The function and regulation of acid-sensing ion channels (ASICs) and the epithelial $\mathrm{Na}(+)$ channel (ENaC): IUPHAR Review 19. Br. J. Pharmacol. 2016, 173, 2671-2701. [CrossRef] [PubMed]

2. Hanukoglu, I. ASIC and ENaC type sodium channels: Conformational states and the structures of the ion selectivity filters. FEBS J. 2017, 284, 525-545. [CrossRef] [PubMed]

3. Hanukoglu, I.; Hanukoglu, A. Epithelial sodium channel (ENaC) family: Phylogeny, structure-function, tissue distribution, and associated inherited diseases. Gene 2016, 579, 95-132. [CrossRef]

4. Kellenberger, S.; Schild, L. International Union of Basic and Clinical Pharmacology. XCI. Structure, Function, and Pharmacology of Acid-Sensing Ion Channels and the Epithelial Na+ Channel. Pharmacol. Rev. 2014, 67, 1-35. [CrossRef] [PubMed]

5. Ortega-Ramírez, A.; Vega, R.; Soto, E. Acid-Sensing Ion Channels as Potential Therapeutic Targets in Neurodegeneration and Neuroinflammation. Mediat. Inflamm. 2017, 2017, 3728096. [CrossRef] [PubMed]

6. Baron, A.; Lingueglia, E. Pharmacology of acid-sensing ion channels-Physiological and therapeutical perspectives. Neuropharmacology 2015, 94, 19-35. [CrossRef]

7. Cristofori-Armstrong, B.; Rash, L. Acid-sensing ion channel (ASIC) structure and function: Insights from spider, snake and sea anemone venoms. Neuropharmacology 2017, 127, 173-184. [CrossRef] [PubMed]

8. Cristofori-Armstrong, B.; Saez, N.; Chassagnon, I.; King, G.; Rash, L. The modulation of acid-sensing ion channel 1 by PcTx1 is $\mathrm{pH}-$, subtype- and species-dependent: Importance of interactions at the channel subunit interface and potential for engineering selective analogues. Biochem. Pharmacol. 2019, 163, 381-390. [CrossRef] [PubMed]

9. Chassagnon, I.; McCarthy, C.; Chin, Y.; Pineda, S.; Keramidas, A.; Mobli, M.; Pham, V.; De Silva, T.M.; Lynch, J.W.; Widdop, R.E.; et al. Potent neuroprotection after stroke afforded by a double-knot spider-venom peptide that inhibits acid-sensing ion channel 1a. Proc. Natl. Acad. Sci. USA 2017, 114, 3750-3755. [CrossRef] [PubMed]

10. Burbach, J.P.; Grant, P.; Hellemons, A.J.; Degiorgis, J.A.; Li, K.W.; Pant, H.C. Differential expression of the FMRF gene in adult and hatchling stellate ganglia of the squid Loligo pealei. Biol. Open 2014, 3, 50-58. [CrossRef]

11. Golubovic, A.; Kuhn, A.; Williamson, M.; Kalbacher, H.; Holstein, T.W.; Grimmelikhuijzen, C.J.P.; Gründer, S. A peptide-gated ion channel from the freshwater polyp Hydra. J. Biol. Chem. 2007, 282, 35098-35103. [CrossRef] [PubMed]

12. Vick, J.S.; Askwith, C.C. ASICs and neuropeptides. Neuropharmacology 2015, 94, 36-41. [CrossRef] [PubMed]

13. Askwith, C.C.; Cheng, C.; Ikuma, M.; Benson, C.; Price, M.P.; Welsh, M.J. Neuropeptide FF and FMRFamide potentiate acid-evoked currents from sensory neurons and proton-gated DEG/ENaC channels. Neuron 2000, 26, 133-141. [CrossRef]

14. Catarsi, S.; Babinski, K.; Séguéla, P. Selective modulation of heteromeric ASIC proton-gated channels by neuropeptide FF. Neuropharmacology 2001, 41, 592-600. [CrossRef] 
15. Deval, E.; Baron, A.; Lingueglia, E.; Mazarguil, H.; Zajac, J.; Lazdunski, M. Effects of neuropeptide SF and related peptides on acid sensing ion channel 3 and sensory neuron excitability. Neuropharmacology 2003, 44, 662-671. [CrossRef]

16. Xie, J.; Price, M.P.; Wemmie, J.A.; Askwith, C.C.; Welsh, M.J. ASIC3 and ASIC1 Mediate FMRFamide-Related Peptide Enhancement of H+-Gated Currents in Cultured Dorsal Root Ganglion Neurons. J. Neurophysiol. 2003, 89, 2459-2465. [CrossRef]

17. Sherwood, T.; Askwith, C.C. Endogenous Arginine-Phenylalanine-Amide-related Peptides Alter Steady-state Desensitization of ASIC1a. J. Biol. Chem. 2008, 283, 1818-1830. [CrossRef]

18. Reimers, C.; Lee, C.H.; Kalbacher, H.; Tian, Y.; Hung, C.H.; Schmidt, A.; Prokop, L.; Kauferstein, S.; Mebs, D.; Chen, C.C.; et al. Identification of a cono-RFamide from the venom of Conus textile that targets ASIC3 and enhances muscle pain. Proc. Natl. Acad. Sci. USA 2017, 114, E3507-E3515. [CrossRef]

19. Ostrovskaya, O.; Moroz, L.; Krishtal, O. Modulatory action of RFamide-related peptides on acid-sensing ionic channels is $\mathrm{pH}$ dependent: The role of arginine. J. Neurochem. 2004, 91, 252-255. [CrossRef]

20. Lingueglia, E.; Deval, E.; Lazdunski, M. FMRFamide-gated sodium channel and ASIC channels: A new class of ionotropic receptors for FMRFamide and related peptides. Peptides 2006, 27, 1138-1152. [CrossRef]

21. Chen, X.; Paukert, M.; Kadurin, I.; Pusch, M.; Gründer, S. Strong modulation by RFamide neuropeptides of the ASIC1b/3 heteromer in competition with extracellular calcium. Neuropharmacology 2006, 50, 964-974. [CrossRef]

22. Frey, E.N.; Pavlovicz, R.E.; Wegman, C.J.; Li, C.; Askwith, C.C. Conformational changes in the lower palm domain of ASIC1a contribute to desensitization and RFamide modulation. PLoS ONE 2013, 8, e71733. [CrossRef] [PubMed]

23. Bargeton, B.; Iwaszkiewicz, J.; Bonifacio, G.; Roy, S.; Zoete, V.; Kellenberger, S. Mutations in the palm domain disrupt modulation of acid-sensing ion channel 1a currents by neuropeptides. Sci. Rep. 2019, 9. [CrossRef] [PubMed]

24. Peeff, N.M.; Orchard, I.; Lange, A.B. Isolation, sequence, and bioactivity of PDVDHVFLRFamide and ADVGHVFLRFamide peptides from the locust central nervous system. Peptides 1994, 15, 387-392. [CrossRef]

25. Konno, K.; Kazuma, K.; Nihei, K. Peptide Toxins in Solitary Wasp Venoms. Toxins 2016, 8, 114. [CrossRef] [PubMed]

26. Petruska, J.C.; Napaporn, J.; Johnson, R.D.; Gu, J.G.; Cooper, B.Y. Subclassified acutely dissociated cells of rat DRG: Histochemistry and patterns of capsaicin-, proton-, and ATP-activated currents. J. Neurophysiol. 2000, 84, 2365-2379. [CrossRef] [PubMed]

27. Garza, A.; López, O.; Vega, R.; Soto, E. The Aminoglycosides Modulate the Acid-Sensing Ionic Channel Currents in Dorsal Root Ganglion Neurons from the Rat. J. Pharm. Exp. Ther. 2010, 332, 489-499. [CrossRef] [PubMed]

28. Donier, E.; Rugiero, F.; Jacob, C.; Wood, J.N. Regulation of ASIC activity by ASIC4-new insights into ASIC channel function revealed by a yeast two-hybrid assay. Eur. J. Neurosci. 2008, 28, 74-86. [CrossRef] [PubMed]

29. Benson, C.J.; Xie, B.; Wemmie, J.A.; Price, M.P.; Henss, J.M.; Welsh, M.J.; Snyder, P.M. Heteromultimers of DEG/ENaC subunits form $\mathrm{H}^{+}$-gated channels in mouse sensory neurons. Proc. Natl. Acad. Sci. USA 2002, 99, 2338-2343. [CrossRef]

30. Xie, J.; Price, M.P.; Berger, A.L.; Welsh, M.J. DRASIC Contributes to pH-Gated Currents in Large Dorsal Root Ganglion Sensory Neurons by Forming Heteromultimeric Channels. J. Neurophysiol. 2002, 87, 2835-2843. [CrossRef]

31. Lingueglia, E.; de Weille, J.R.; Bassilana, F.; Heurteaux, C.; Sakai, H.; Waldmann, R.; Lazdunski, M. A Modulatory subunit of acid sensing ion channels in brain and dorsal root ganglion cells. J. Biol. Chem. 1997, 272, 29778-29783. [CrossRef] [PubMed]

32. Qiu, F.; Liu, T.T.; Qu, Z.W.; Qiu, C.Y.; Yang, Z.; Hu, W.P. Gastrodin inhibits the activity of acid-sensing ion channels in rat primary sensory neurons. Eur. J. Pharmacol. 2014, 731, 50-57. [CrossRef]

33. Sun, X.; Cao, Y.B.; Hu, L.F.; Yang, Y.P.; Li, J.; Wang, F.; Liu, C.F. ASICs mediate the modulatory effect by paeoniflorin on $\alpha$-synuclein autophagic degradation. Brain Res. 2011, 1396, 77-87. [CrossRef] [PubMed]

34. Diochot, S.; Baron, A.; Rash, L.; Deval, E.; Escoubas, P.; Scarzello, S.; Salinas, M.; Lazdunsky, M. A new sea anemone peptide, APETx2, inhibits ASIC3, a major acid-sensitive channel in sensory neurons. EMBO J. 2004, 23, 1516-1525. [CrossRef] [PubMed] 
35. Schroeder, C.I.; Rash, L.D.; Vila-Farrés, X.; Rosengren, K.J.; Mobli, M.; King, G.F.; Alewood, P.F.; Craik, D.J.; Durek, T. Chemical synthesis, 3D structure, and ASIC binding site of the toxin mambalgin-2. Angew. Chem. Int. Ed. Engl. 2014, 53, 1017-1020. [CrossRef]

36. Salinas, M.; Besson, T.; Delettre, Q.; Diochot, S.; Boulakirba, S.; Boulakirba, S.; Douguet, D.; Lingueglia, E. Binding site and inhibitory mechanism of the mambalgin-2 pain-relieving peptide on acid- sensing ion channel 1a. J. Biol. Chem. 2014, 289, 13363-13373. [CrossRef]

37. Rodríguez, A.A.; Salceda, E.; Garateix, A.G.; Zaharenko, A.J.; Peigneur, S.; López, O.; Pons, T.; Richardson, M.; Díaz, M.; Hernández, Y.; et al. A novel sea anemone peptide that inhibits acid-sensing ion channels. Peptides 2014, 53, 3-12. [CrossRef]

38. Chen, X.; Kalbacher, H.; Gründer, S. Interaction of acid-sensing ion channel (ASIC) 1 with the tarantula toxin psalmotoxin 1 is state dependent. J. Gen. Physiol. 2006, 127, 267-276. [CrossRef]

39. Baron, A.; Diochot, S.; Salinas, M.; Deval, E.; Noël, J.; Lingueglia, E. Venom toxins in the exploration of molecular, physiological and pathophysiological functions of acid-sensing ion channels. Toxicon 2013, 75, 187-204. [CrossRef]

40. Baconguis, I.; Gouaux, E. Structural plasticity and dynamic selectivity of acid-sensing ion channel-spider toxin complexes. Nature 2012, 489, 400-405. [CrossRef]

41. Salceda, E.; Garateix, A.; Soto, E. The sea anemone toxins BgII and BgIII prolong the inactivation time course of the tetrodotoxin-sensitive sodium current in rat dorsal root ganglion neurons. J. Pharmacol. Exp. Ther. 2002, 303, 1067-1074. [CrossRef] [PubMed]

42. Bevan, S.; Hothi, S.; Hughes, G.; James, I.F.; Rang, H.P.; Shah, K.; Walpole, C.S.; Yeats, J.C. Capsazepine: A competitive antagonist of the sensory neurone excitant capsaicin. Br. J. Pharmacol. 1992, 107, 544-552. [CrossRef] [PubMed]

(C) 2019 by the authors. Licensee MDPI, Basel, Switzerland. This article is an open access article distributed under the terms and conditions of the Creative Commons Attribution (CC BY) license (http://creativecommons.org/licenses/by/4.0/). 